\title{
Research and Practice on Non-English Major Master Candidate English Hierarchical Teaching Reform
}

\author{
Chunfen Feng
}

Dalian Jiaotong University

fcf67@163.com

Keywords: non-English major master candidate; English teaching; hierarchical; practice

\begin{abstract}
This paper studied feasibility and achievements of ordinary college and university non-English major master candidate hierarchical English teaching and proposed the reform direction based on the 3-year hierarchical teaching practice centering on master candidates enrolled in 2010, 2011 and 2012 and the 4 layers of students and teaching objectives, teaching content, teaching method and teaching evaluation, and comparison with students enrolled in 2009 without experiencing hierarchical teaching in terms of CET-6 pass rate.
\end{abstract}

\section{Introduction}

Master candidate English teaching is higher than bachelor candidate English teaching. Coming from all over the country, master candidates are characterized by different English proficiencies upon enrolment, different English proficiencies from the same department, the same major and the same class. Some passed CET-4 and CET-6 in university, while others not. In addition, in recent years, expanded enrolment has resulted in quality drop. In the past, only diligent students selected to work on master degree and could be enrolled while now some students select to work on master degree because of high employment pressure. It can be said that the overall quality witnesses a downward trend. In addition, students of arts and science are obviously different in CET-4 and CET-6 pass rates. Some fail, and some only have enrolment 30 points. Moreover, most students have imbalanced development in listening, speaking, reading, writing and translating, better in reading, but unqualified in speaking or writing. How can they handle interviews and exchanges after graduation? How can they meet the requirements stipulated in the teaching program, namely, "competent in reading, writing and translating and listening and speaking, using English as a tool for professional study and research"? Students from different teaching quality areas, with different foundations and capacities, and English proficiency share the same objectives and teaching materials, seriously hampering their interest and affecting their improvement.

\section{Determining teaching reform objectives}

CET-6 remains vital to employment, highlighting its importance. To improve the loser's self-confidence in employment interviews, it is necessary to conduct CET-6 special and comprehensive training and make the unsuccessful examinee pass CET-6, properly training them in English speaking to handle interviews. The successful examinees should focus on English listening, speaking, writing and translating, English application, humanistic quality and academic exchanges, academic research ability, laying down a foundation for their future development.

\section{Teaching reform practice}

According to statistics, this university had 321 enrolments in 2009, with 95 passing CET-6, accounting for 29.5\%, and 398 enrolments in 2010, with 126 people passing CET-6, accounting for 32\%. Examinees failing in CET-6 t included those failing in CET-4. The pass rate was only about 
30\%. To understand actual English proficiency and demands of enrolments of 2009, a questionnaire survey was conducted in the second semester. 113 passing it were more likely to strengthen their listening and speaking, and 235 asked for CET-6 past exam paper/mock exam paper or related textbooks or expanded textbooks, accounting for $73 \%$. The survey results also showed only $23.2 \%$ were satisfied with traditional English teaching, 51.9\% felt average. 76.8\%, $72.9 \%$ and $42.7 \%$ respectively expected improvement in listening, speaking and reading. $62.3 \%$ took listening as the biggest obstacle. Most of the unsuccessful examinees expected CET-6 past exam paper/mock exam paper or master candidate textbooks, and expanded CET-6 content, while most of the successful examinees expected to improve listening and speaking, or listening, speaking, reading, writing and translating simultaneously, indicating great differences. The faculty found students eager to pass CET-6 focused on CET-6, affecting teaching and learning results. Too much CET-6 was beyond their expectation. Based on "putting students first", we conducted hierarchical teaching research and practice to meet different needs of students with different English proficiency.

From the perspective of pedagogy, the teaching goal is the direction and starting point, teaching content is the carrier of the course goal, teaching method is the means to realize the goal, evaluation system is the tool to detect the achievement of the goal, and the teaching quality consists of these 4 elements. Therefore we conducted 3-year hierarchical teaching practice centering on master candidates enrolled in 2010, 2011 and 2012 and the 4 layers of students and teaching objectives, teaching content, teaching method and teaching evaluation and comparison with students enrolled in 2009. The faculty could adjust teaching methods and select teaching materials accordingly.

\subsection{Layers of students and teaching objectives}

Master candidates enrolled in 2010, 2011 and 2012 were divided into 2 layers, namely A and B, according to CET-6 results. Layer A took applied skills and cross-cultural communications as the main teaching content, focusing on academic exchange and research capabilities, improving their comprehensive cultural literacy and international horizons to adapt to China's economic and social development and international strategy. Layer B took English test and comprehensive application capacity, English speaking and CET-6 as the main objectives, making them competent in English exchange in future work and social interactions. If they passed CET-6 in the first semester, the students might apply for Layer B from Layer A in the second semester.

\subsection{Teaching content layer}

Layer A students selected Shanghai Foreign Language Education Press's general higher education "Tenth Five-Year Plan" national programmed teaching material senior English reading and writing - multicultural speculation and senior English listening and speaking materials. The original intensive textbook covered a wide range of topics such as cross-cultural communication, gender issues, environmental issues, behavioral issues, and population issues, and other extensive knowledge of humanities and social sciences, and common concerns of human beings, viewpoints of multiple disciplines, combining with English learning and training of positive, critical, thinking abilities and ways, making students understand the characteristics of modern society and differences between Chinese and Western cultures, laying down a solid foundation for their international exchanges. Students obtained English language and English culture knowledge, and the comparative culture, international culture, life culture, and social culture, expanding their knowledge and improving their overall quality.

The original listening and speaking materials were selected from classic lectures of Western colleges and universities, news media reports, professional interviews and other fresh materials since 1995, covering physical and mental health, life processes, intelligence, nonverbal information, interpersonal relationships and other topics.

Layer B teaching materials were selected from Wang Changxi CET-6 mock or real exam papers and Mao Ronggui Spark CET-6 mock exam papers. Intensive reading focused on CET-6 special and comprehensive training, especially listening. 


\subsection{Teaching method layer}

To achieve Layer A teaching objectives, the faculty put students first, taking multiple teaching methods, such as interactive teaching method, discussion teaching method, task teaching method, heuristic teaching method, comparison method, modern multimedia teaching method, and interactive teaching method, creating the fine classroom atmosphere, organizing brainstorming, developing divergent thinking ability. For example, there was a text concerning American values. Inspiring students to compare the values of the Chinese people and American people, understand the Chinese and Western Cultural differences, conducting critical thinking and individual development and independent learning. There was an article about George W. Bush, encouraging students to understand the history of the United States and outstanding American presidents, asking them to complete extracurricular learning tasks, popularizing US historical knowledge, political knowledge, cultivating their humanistic quality. Multimedia classrooms and language labs introduced film and television works. Martin Luther King's speech "I have a dream" made students understand parallelism, analogy and metaphor. Film and television works stimulated their interest in learning, helping them with language learning, target language culture familiarity, and world outlook and outlook on life. In addition, making them enjoy the excellent English songs, English lyrics, and improving listening.

Layer B students focused on reading, listening, translating and writing, itemized test, explanation and training, comprehensive training, comprehensive simulation, and comprehensive test, striving to improve their CET-6 pass rate. Most students took listening as the biggest obstacle, challenging and centering on dialogues, texts, and dictations, and constant training. Writing required idea explanations, language organization, some wonderful sentences and even paragraphs memory. Fast reading required fast completion and explanation against the answer and solutions. Translating checked grammar foundation and knowledge, such as: virtual tone, flip, and non-predicate form adverbial. The faculty had to teach basic skills and ask students to get familiar with relevant test essential, strengthening vocabulary training so as improve their listening, speaking, reading and writing. The faculty should constantly encourage and inspire students to take various methods, such as word formation, collocation and pronunciation, helping them with their vocabulary expansion, memory and guess.

\subsection{Teaching evaluation layer}

To obtain accurate and effective teaching feedback, it was necessary to assess students of various layers. According to different teaching objectives and requirements, the papers should be fair and rational. The faculty should assess Layer A students through their attendance, oral presentation, audition, homework (translation, abstract, and small paper), normal results and final results. Layer B students took closed-book exams and final assessment, taking CET-6 as standards, including writing, reading, listening, comprehensive reading, translating, and cloze.

\section{Teaching reform data analysis and practical results}

Questionnaires indicated consistency between enrolments in 2009 and 2010 in terms of "improvement in English", "obstacles to CET-6" and "ideal curriculum for losers" and "ideal curriculum for the successful". They recognized "listening and speaking" and "and CET-6 centering”. It was interesting that CET-6 losers expected CET-6 centering, but 52.9\%, disapproved, and $78.7 \%$ expected CET-6 pass. 32.5\% depended on time availability, showing their low self-discipline and self-learning awareness, resulting in the low pass rate. Statistical data showed master Grade 1 had a higher pass rate, master Grade 2 depended on time availability. According to the policies introduced by the Ministry of Education, from 2014 onwards, all the master candidates became self-supported, striving for scholarships to supplement their tuition fees, resulting in greater scholarships and competitions. Therefore, it was necessary to set different goals based on their different demands, conducting comprehensive, objective, scientific and accurate assessment. It was 
consequently necessary to design a comprehensive evaluation system for master candidates, conducting comprehensive and diagnostic evaluations, evaluating and confirming their interest, attitude, participation, and language development, recognizing their strengths and weaknesses, and assisting the faculty in improving teaching effectiveness.

CET-6 pass rate table

\begin{tabular}{|c|c|c|c|c|c|}
\hline Time & \multicolumn{2}{|c|}{ Number of participants } & \multirow{2}{*}{$\begin{array}{l}\begin{array}{l}\text { Number of } \\
\text { the } \\
\text { successful }\end{array} \\
19\end{array}$} & \multirow{2}{*}{$\begin{array}{l}\text { Pass rate } \\
9.4 \%\end{array}$} & \multirow{2}{*}{$\begin{array}{l}\text { Remarks } \\
\begin{array}{l}\text { Un-layered } \\
\text { teaching }\end{array}\end{array}$} \\
\hline December 2009 & $\begin{array}{l}\text { Enrolment } \\
\text { in } 2009\end{array}$ & 201 & & & \\
\hline June 2010 & $\begin{array}{l}\text { Enrolment } \\
\text { in } 2009\end{array}$ & 203 & 26 & $12.8 \%$ & $\begin{array}{l}\text { Un-layered } \\
\text { teaching }\end{array}$ \\
\hline \multirow[t]{2}{*}{ December 2010} & $\begin{array}{l}\text { Enrolment } \\
\text { in } 2009\end{array}$ & 244 & 33 & $13.5 \%$ & $\begin{array}{l}\text { Un-layered } \\
\text { teaching }\end{array}$ \\
\hline & $\begin{array}{l}\text { Enrolment } \\
\text { in } 2010\end{array}$ & 248 & 39 & $15.7 \%$ & Layered teaching \\
\hline \multirow[t]{2}{*}{ June 2011} & $\begin{array}{l}\text { Enrolment } \\
\text { in } 2009\end{array}$ & 140 & 13 & $9.29 \%$ & $\begin{array}{l}\text { Un-layered } \\
\text { teaching }\end{array}$ \\
\hline & $\begin{array}{l}\text { Enrolment } \\
\text { in } 2010\end{array}$ & 198 & 42 & $21.21 \%$ & Layered teaching \\
\hline \multirow[t]{3}{*}{ December 2011} & $\begin{array}{l}\text { Enrolment } \\
\text { in } 2009\end{array}$ & 79 & 9 & $11.4 \%$ & $\begin{array}{l}\text { Un-layered } \\
\text { teaching }\end{array}$ \\
\hline & $\begin{array}{l}\text { Enrolment } \\
\text { in } 2010\end{array}$ & 162 & 35 & $21.6 \%$ & Layered teaching \\
\hline & $\begin{array}{l}\text { Enrolment } \\
\text { in } 2011\end{array}$ & 233 & 46 & $19.74 \%$ & Layered teaching \\
\hline \multirow[t]{3}{*}{ June 2012} & $\begin{array}{l}\text { Enrolment } \\
\text { in } 2009\end{array}$ & 28 & 2 & $7.1 \%$ & $\begin{array}{l}\text { Un-layered } \\
\text { teaching }\end{array}$ \\
\hline & $\begin{array}{l}\text { Enrolment } \\
\text { in } 2010\end{array}$ & 104 & 10 & $9.61 \%$ & Layered teaching \\
\hline & $\begin{array}{l}\text { Enrolment } \\
\text { in } 2011\end{array}$ & 225 & 38 & $16.9 \%$ & Layered teaching \\
\hline \multirow[t]{3}{*}{ December 2012} & $\begin{array}{l}\text { Enrolment } \\
\text { in } 2010\end{array}$ & 71 & 8 & $11.27 \%$ & Layered teaching \\
\hline & $\begin{array}{l}\text { Enrolment } \\
\text { in } 2011\end{array}$ & 144 & 17 & $11.81 \%$ & Layered teaching \\
\hline & $\begin{array}{l}\text { Enrolment } \\
\text { in } 2012\end{array}$ & 282 & 56 & $19.86 \%$ & Layered teaching \\
\hline
\end{tabular}

\section{Acknowledgement}

This paper was the research results of "Research and Practice on Non-English Major Master Candidate English Hierarchical Teaching Reform”, a project topic of Liaoning Province Master Candidate Education Innovation Program in 2010 (No.: lnxwb201044).

\section{References}

[1] Zhou Junping, Faculty Discourse and Second Language Acquisition [J]. Foreign Language Teaching, 2006,27 (3): 69.

[2] Liu Runqing, Foreign Language Teaching Research Methods [M]. Beijing: Foreign Language Teaching and Research Press, 1999. 
[3] Tan Xiaojing, Non-English Major Master Candidate English Teaching Reform [J], The Border Economy and Culture, 2007 (4)

[4] You Hongyun, Non-English Major Master Candidate English Teaching Reform Acad J Guangdong Coll Pharm, 2007 (4)

[5] Gan Xiaoya. Master Candidate Public English Speaking Teaching New Ideas [J] Journal of Chongqing Institute of Technology (Natural Science Edition), 2007 (4)

[6] Li Hong, Some Ideas on Non-English Major Master Candidate English Teaching [J]. Gansu Science and Technology, 2001 (5)

[7] Guo Jirong, Wang Fei, Wang Li, Master Graduate English Teaching Reform Exploration and Practice [J]. China Higher Education Research, 2006 (3) 